\title{
Musical Effects in Corporate Culture Modeling
}

\author{
Weiwei Qin \\ School of Education \\ Shandong Women's University \\ Jinan, China \\ Email:769458655@qq.com
}

\begin{abstract}
With the rapid development of economy, accelerating paces of people's living and fiercer social competition, people's demand on music is no longer remain in the playing on form level, but it to higher level such as internal culture promoting, economic developing, and people's emotional cultivating, and so on. With continuing development of domestic economy in recent years, perfection of marketing economy, music has domestically affected economic building and corporate culture modeling. This paper is about to deeply analysis music's effect in corporate culture modeling.
\end{abstract}

This paper is mainly divided into three parts, The Introduction part gives a brief abstract on music's role in corporate culture modeling, and the purpose and significance for this paper writing; The formal parts of the paper separately describe music's effects in corporate culture modeling, aim to promote musical effects in corporate culture modeling through a deeper analysis; The last part gives a summary on the issues reflected in the musical effects on corporate culture modeling.

\section{Keywords: Music; Marketing Economy; Corporate Culture}

\section{INTRODUCTION}

Nowadays, social competition has become more and more intensive, and competition between enterprises has penetrated into the cultural level. An enterprise has to improve its soft power, is corporate culture to grow healthily and stably. Corporate culture or organizational culture is established to solve problems in enterprise survival and development, and is a basic belief and perceptions followed and effectively shared by members of organizations. It reflects the core value of an enterprise's management and operation and organizational behaviors generated by this value; it represents unique cultural image of an organization consisting of value, beliefs, rituals, symbols, and ways of doing things. The molding of excellent corporate culture needs to be supplemented with a series of expression skills, and among which music occupies an irreplaceable position in the dissemination of corporate culture. In recent years, as the scientific management of enterprises has begun to take shape, development of corporation culture has gradually become a focus. It is roughly divided into three levels: material culture, institutional culture, and spiritual culture. Music assumes the chief role of spiritual culture. Just as Jack Welch, a well-known management scientist and former GE president, "A positive corporate culture is the source of the company's invincible power. Yu Guangyuan, a well-known Chinese economist, also believes: "In terms of development issues, third-rate companies mainly rely on production. Second-rate companies rely mainly on marketing, and firstrate companies rely mainly on culture."[1]. This paper gives an in-depth analysis of the role of music in six aspects: cultivating people's sentiments, enhancing their internal cohesion, forming corporate core values, shaping corporate image, enhancing employee creativity and imagination, and advertising.

\section{CUltivating PEOPlE'S SENTIMENTS------INTEGRITY AND INSPIRING SPIRIT}

It is our country's fine tradition to "Being a good person before doing things". An enterprise should attach great importance to the cultivating of employees' moral sentiments. Music plays a significant role in this aspect. However, music does not come from nowhere. Instead, it brings nature's inspiring spirit deep into people's heart in the form of abstract musical notes, and then helps internalize into people's own spiritual food, allowing people to absorb moral sunshine and rain. People can also inject their own social experience into understanding of lyrics and absorb the positive energy in music. The lyric "Sweet job, Sweet job gives me a bright tomorrow, Sweet songs, Sweet songs in the air" in the theme song "Life Sweeter than Honey" in movie "Sweet Job" vividly conveyed the sweet pleasures in work. A beautiful life was right in front of us. The song showed a sense of pride and happiness at work through every line in the song. Meanwhile "our tomorrow" has widened the rhythm, forming a strong contrast with former lines, repeating "tomorrow" three times at the end to raise the mood to the highest point, feelings of happiness raise in people's heart. Such inspiring music fills every corner of our lives and makes every tired nerve to dance. With such inspiring music why do you worry that negative emotions will within the company? For another example, in this fastchanging Electronic Era, it is very common that people loss their sense of self-identity. The line in the song "I Believe" sung by Yang Pei'an, "I want to fly to heaven, stand with the sun side by side, the world waiting for me to change, put aside the worries, and courage to move forward, I'm right here in the middle of the stage." helps people build their confidence to move forward, to find a sense of belonging and 
self-motivation in the vast sea of people. It brings us from the vast ocean of the people to the center of the world stage and gives people beautiful hopes of future. Good music can always bring people with unlimited positive energy, quietly influences on people's moral sentiments. People always find hope in music.

The reason why music can become an important means for companies to cultivate employees' morality and personality lies in the artistic beauty of music. It is a blend of culture and art, reflecting the profound connotations of truth, kindness, and beauty. Music's artistic character sublimates people's inner feelings, purifies the people's mind, enhance connotation of life, make people relax in the music, and throw off troubles away while singing. When facing repeating work or work with high competitive pressures, proper music can help us evoke passion for work and relax our tight nerves. The pressure brought by today's society will inevitably cause many employees to experience emotional instability, psychological imbalances, and large fluctuations in mood. At this moment, the guidance of active music is even more necessary, helping employees learn to control and adjust their emotions, allowing negative emotions dissipated along with the melody of music, and investing in the work with a new look and enthusiasm.

\section{SOLIDARITY AND UNITY---- SPIRITUAL IMPETUS}

Excellent corporate culture can often lead to more challenging and innovative activities and inject energy for the sustainable development of the company. The modeling of corporate culture often determines the position of company's development. When enjoying the convenience brought by science and technology, one has to pay attention to the fact that the emotional communication between people gradually becomes blurred. Science and technology brings different degrees of influence to people's mind and spirit. However, as a carrier of emotions, music, a lyrical art just adds a defense wall to people's loss of emotions, injecting our souls with gentle, sweet singing voices, and emotional interaction among people. As a carrier of people's emotions, music expresses people's thoughts and emotions regardless of the way they perform.

Music is no longer the music in the traditional meaning. What people value more is its cultural value and commercial value. Companies enhance their sense of cooperation and corporate cohesion through music. Most companies have created songs that reflect the company's connotation and corporate character, demonstrating the spirit of employees and promote corporate image through performing these songs, making employees feeling the teamwork spirit "working hard together" to enhance friendship among employees while performing, fostering the sense of ownership, and improving the sense of identity, centripetal force and cohesion between employees and the company and between employees and managers. There is no doubt that music injects a strong internal impetus to the sustainable development of the company.
Music enhances communication skills and corporate cohesion. Everything born with its social attributes. The social attribute of music is bringing people closer to each other and encouraging them to make first acquaintance. Music has an obvious character of communication. Every person in society is not a lonely individual and has the need for communication. Musical activities organized by the company create a relaxing platform for employees. With the soft melody of music, people can easily unload various masks given by societies, treat each other with intent, which effectively narrows the psychological distance between each other, gradually forms a network of interpersonal relationships, and enhances the cohesiveness among employees.

\section{DEMONSTRATE CORPorate VAlUE----Highlight THE THEMES OF THE TIMES}

Corporate value is the core part of corporate culture. It has been continuously formed since a company was born, and guides the direction of the company's progress. If a company wants to take the lead in the fiercely competitive economic market, it is necessary to use music as a media of emotional communication to build a brand image, and make full use of music's special character to interpret and promote the company's core values. The most important issue in the implementation of corporate values is to ensure that employees can understand the meaning of these values and fully affirm and transform this concept into their own values. Music is playing a very important role in implementation of corporate values and meanings. Rather than the music in the strict meaning sung by composer, the music here is easy-tospeak, easy-to-understand song written with company's own characters. In fact, labor and life of humans in the primitive era is developed along with music, the two are tightly bonded together. In light of this fact, music is directly generated from human labor, that is, music originates from human labor, servers human labor, and at the same time, increase efficiency of labor. For example, the folk song "Flowers" popular in northwest China, is a song in a relaxing rhyme, and not to any musical form. With its own character, companies can create songs representing corporate image and values. For example, lyrics such as "Happy people always own, people who own are always happy, WANGGUANG roasted beef' are always easy to understand, and is easy for the majority of consumers to realize corporate values of the company----to build a brand with love and happiness, to remind employees that they are doing a job with happiness and are creating happiness for others through responsibilities. The company's values and brand image will be accepted by the people, penetrate into people's hearts, and widely sung along with melody of the songs.

It will make employees to create strong inner drive force if perfectly integrating the songs with unique corporate characters and highlighting the themes of the times with company's construction of spiritual civilization. Music is no longer simple melody but a combination of the times' 
characteristics and a company's characteristics. It can rise public's sense of identity when highlighting the themes of the times, and at the same time, subtly bring corporate values and management conceptions into people's field of view. It is vital for a company to choose a song that represents its corporate values. People always love elegant and bright melody, which is also a good "glue" for employee relationship. A song reflecting the main theme of the times can give people endless positive energy, encourage them to move forward; hearing from the song of the company often arouse employees' sense of responsibility and sense of pride.

\section{IMPROVE CORPORATE IMAGE----ACHIEVE WIN-WIN SITUATION IN THE FIELD}

Corporate image modeling is a vital part in company's market competitiveness, just like your appearance largely decides how others feel about you. Just like people's makeup and wearing, corporate image can be modified through an appropriate way, and culture of music is exactly the important stylist for corporate image. In light of this fact, in order to improve the competitiveness, many companies invested a large part of their funds in image modeling, so that they can create and stabilize a good corporate image. In order to allow consumers to understand their companies from a various aspects, many companies have noticed music is playing an important role in the shaping of corporate image. Music into people's minds without notice and their hearts with its affinity. The public image of an enterprise largely determines its earnings and determines the viability of the company. Good corporate image not only benefits the enterprise, but also can gain considerable social effects. A good corporate is not equivalent to a good profit, but companies can gain people's good impressions on them, and enter into people's vision field through building a good image. Through music, companies can enter into people's hearts in short time, so that they can achieve the purpose of showing corporate image to public. A good corporate image can gradually improve employee's appearance, improve employee's awareness of self-improvement and selfdiscipline and arouse employee's sense of pride and sense of responsibility to the company. Many world-famous enterprises such as Bosideng, Proctor \& Gamble, Pepsi and Sony have won a big profit from culture of music, which seems to be nothing to do with corporate development. These enterprises let people enter into them through music, promote corporate images, and bring themselves with a large number of consumers. For example, during the singing competition on the 5th Corporate Culture Art Festival of Guangdong Province in 2006, many companies have demonstrated their new looks and images, which further promoted corporate culture development, and make music became potential and supportive strength of corporate culture development. Music is a business card of a company, and a sign of corporate image and brand. Musical culture has promoted the economic development, and at the same time economic development has put forward higher requirements on the development of the musical culture, which has achieved a win-win situation between the fields.

\section{IMAGINATION AND CREATIVITY---- FOUNDATION OF DEVELOPMENT}

The reason why music can promote imagination and creativity is that it is very infectious and influential in emotion: relaxing and soft music can eliminate the emotion of anxious and unsettling while exciting music can make people's mind highly stimulated and make people think actively and act passionately. In addition, musical works often created with material from a large range of fields, and composers often think of the point of views that ordinary people do not think of, boldly abstract the essence of life, and create great musical works. When these works are conveyed to the audience through musical instrument, singing, and second-degree creation, they touch the emotions of the listener, bring them into the world of music, and at the same time listeners can feel the soul and charm of music. Along with the music, people's mind will be lead to the climax of imagination activity. Employee's imagination and creativity is vital for a company's development. For example, the designer phosphor powder to light switch of a wellknown brand, which greatly increased the volume of this product. In addition, because of this new idea, customers can stop searching light switch in dark anymore. In conclusion, we should take advantage of music's special effects on people's imagination and creativity to foster employees with highly creative talents.

\section{ADVERTISEMENT AND PUBLICITY ----WIDELY KNOWN BY EVERYONE}

Music comes from life and serves life. Recently, many companies have released that music has special value on improving corporate image and increasing commercial effects, thus they followed this tendency, creating elaborate musical works, making them into advertising video to widely publicize, which has achieved a great public effects. After these songs are widely popularize public, the fame of the company and its products are automatically known by public. Music has become a vital part of corporate culture modeling, and is concerned and adopted by more and more companies. An impressive corporate advertising song will surely bring about a strong advertising effect for the company's product planning and promotion, and it has important value that can not be ignored in the promotion and promotion of the company's cultural development. For example, the musical commercial of Yida Gum is deeply remembered and widely sung by public because of its slogan "Hey, it is your Yinda! - Nope, it is yours." This example proves that Chinese entrepreneurs have begun to realize that the use of music in the process of corporate advertising marketing has a particularly important influence. Companies can use their popular advertising music to improve their popularity and establish their own corporate image. The advertisements of well-known brands such as Baihei, Nerve Platinum, and 
Huiyuan have already penetrated into the people's hearts. Such music can occupy people's hearts without being noticed, and become the music often heard from people's mouths, mobile phones and streets. The influence of the above brands naturally expands with the music around the world. People often firstly think of the music related to certain product they are familiar with when they purchase certain products. From this aspect, music can, to some extent, also own the positive effect on enhancing corporate advertising effectiveness.[1]

\section{CONCLUSION}

Music comes from production, which determines the practicality of it itself; people entrust their feelings and thoughts to music, which determines the cultural nature of music. From this aspect, the two features have build up a bridge between corporate culture and musical cultural, which seems have nothing to with each other. If a company wants to find a place and stand still in the society where science and technology is highly developed, economy has grown rapidly, and full of competitions, it has to improve its soft power, which requires a close connection between music and company. Music's role in corporate culture modeling becomes more and more important. To make music play its unique role in corporate culture modeling, we need to deeply appreciate the meaning behind the music and discover the potential value of music.

\section{REFERENCES}

[1] Wenhui Ye "On the Role of Music in the Corporate Culture Modeling" [J] Modern Corporate Education 2012(10)

[2] Sihai Xu, Xiaojuan Wang "Musical Effects in Corporate Culture Modeling " [J] Corporate Research, 2011(12) 